\title{
Self Efficacy Dan Kecemasan Mengerjakan Skripsi Pada Mahasiswa
}

\author{
Suyanti ${ }^{1}$ \\ Albadri \\ 1,2 Fakultas Ilmu Sosial dan Humaniora, Universitas Ibrahimy Situbondo \\ Email: suyantimpsi56@gmail.com
}

\begin{abstract}
Thesis is a graduation requirement for students, of course it will cause some students to feel anxious at the moment working on. The anxiety could arise because of some things that are considered threatened. Besides anxiety can also arise due to low confidence in the ability of self or self-efficacy. This study was conducted to examine the correlation between self-efficacy with the anxiety of students who are working on the thesis. The scale used in this study is the scale of self-efficacy and anxiety scales. The subjects used in this research were 161 students from the Universitas Ibrahimy who was working on a thesis. The results showed a negative relationship between self-efficacy with anxiety in students who are working on the thesis with the calculated product moment correlation $(r=-0.606, p=$ $0.000, p<0.01$ ).
\end{abstract}

Keywords : Self-efficacy, anxiety, students, thesis

\begin{abstract}
Abstrak
Skripsi merupakan syarat kelulusan bagi mahasiswa, tentunya hal tersebut akan menyebabkan sebagian mahasiswa merasa cemas pada saat mengerjakan. Kecemasan tersebut bisa muncul karena beberapa hal yang dianggap mengancam. Selain itu kecemasan juga dapat muncul karena rendahnya kepercayaan terhadap kemampuan diri atau self efficacy. Penelitian ini dilakukan untuk menguji korelasi antara self efficacy dengan kecemasan mahasiswa yang sedang mengerjakan skripsi. Skala yang digunakan dalam penelitian ini adalah skala self efficacy dan skala kecemasan. Subjek yang digunakan dalam penelitian ini berjumlah 161 orang mahasiswa Universitas Ibrahimy yang sedang mengerjakan skripsi. Hasil penelitian menunjukkan adanya hubungan negatif antara self efficacy dengan kecemasan pada mahasiswa yang sedang mengerjakan skripsi dengan hasil perhitungan korelasi product moment ( $r=-0,606 ; p=0,000 ; p<0,01)$. Kata kunci : Self efficacy, kecemasan, mahasiswa, skripsi
\end{abstract}




\section{Pendahuluan}

Skripsi sering kali diilustrasikan sebagai suatu hasil dari karya tulis mengenai penelitian yang dilakukan guna mendapatkan gelar sarjana S1. Skripsi membahas mengenai permasalahan dan fenomena dalam bidang ilmu yang mengunakan kaidahkaidah tertentu yang berlaku. Skripsi bertujuan agar mahasiswa mampu menyusun dan menulis suatu karya ilmiah, sesuai dengan bidang ilmunya. Mahasiswa yang mampu menulis skripsi dianggap mampu memadukan pengetahuan dan keterampilannya dalam memahami, menganalisis, menggambarkan, dan menjelaskan masalah yang berhubungan dengan bidang keilmuan yang diambilnya. Skripsi merupakan persyaratan untuk mendapatkan status sarjana (S1) di setiap Perguruan Tinggi Negeri (PTN) maupun Perguruan Tinggi Swasta (PTS) yang ada di Indonesia.

Berdasarkan survey yang telah dilakukan dengan mengunakan interview dan observasi, peneliti menemukan beberapa hal yang membuat seseorang merasa cemas dalam proses pengerjaan skripsi. Pertama, seringnya diminta untuk melakukan revisi oleh dosen pembimbing yang akhirnya menurunkan kepercayaan diri dan motivasi mahasiswa, revisi yang dilakukan ini meliputi penulisan yang tidak sesuai dengan ketentuan, latar belakang yang tidak memiliki dasar yang kuat, teori yang tidak tepat dan disarankan untuk menganti judul dengan alasan sudah banyak penelitian yang sama hingga dirasa mengurangi originalitas penelitian. Kedua, pertanyaan orang-orang disekitar baik orang tua ataupun teman mengenai skripsi yang sudah dijalaninya. Ketiga, teman yang lebih cepat pengerjaanya dari seminar proposal hingga sidang dan wisuda, meskipun terkadang membuat seseorang termotivasi tetapi tidak sedikit pula mahasiswa yang merasa cemas dengan keberhasilan mahasiswa lain tersebut. Beberapa situasi tersebut membuat beberapa dari mereka merasa takut saat saat bertemu dengan dosen dan memilih untuk menghindar. Ada pula yang merasa takut untuk pulang kerumah dan mengangkat telepon dengan alasan takut mereka bertanya mengenai skripsinya. Selain itu ada pula yang mencari kesibukan lain seperti bekerja full time atau part time, untuk mengalihkan kecemasan saat mengenai skripsi, hingga terkadang menunda mengerjakan skripsinya dengan alasan kariernya mulai menanjak.

Kecemasan dapat dipengaruhi oleh beberapa hal. Kepribadian memiliki hubungan kecemasan salah satunya pada dimensi tempramental yang merupakan manifestasi dari gangguan kecemasan (Marco, 2013). Regulasi positive afektif juga memiliki hubungan dengan kecemasan. Regulasi membuat kontribusi yang unik dan substansial untuk memprediksi setiap gangguan kecemasan (Eisner, L., Johnson, S., \& Carver, C, 2009). Sementara itu Bagi orang-orang dengan sedikit kecemasan sosial, hubungan kedekatan ditingkatkan dari waktu ke waktu ketika emosi negatif tersebut diungkapkan secara terbuka sedangkan kerusakan hubungan ditemukan bagi mereka lebih mungkin untuk menahan emosi. Pola sebaliknya ditemukan untuk orang dengan kecemasan sosial yang lebih besar sehingga hubungan kedekatan ditingkatkan dari waktu ke waktu bagi mereka lebih mungkin untuk menahan emosi negatif. Terkait temuan kecemasan sosial ditemukan untuk perbedaan antara perasaan yang diinginkan dan aktual kedekatan dari waktu ke waktu. 
Ada 6 faktor kognitif yang menyebabkan kecemasan. Pertama, prediksi berlebihan pada rasa takut atau cemas dalam situasi-situasi yang dialami seseorang. Kedua, keyakinan yang self-defeating atau irasional. Ketiga, sensifitas berlebihan terhadap ancaman, orang-orang seperti ini mempersepsikan bahaya pada situasi yang dianggap aman oleh orang lain. Keempat, sensitifitas kecemasan yang biasanya diartikan sebagai rasa takut terhadap kecemasan dan beberapa gejala yang berkaitan dengan kecemasan. Kelima,salah mengatribusikan sinyal-sinyal tubuh. Keenam, self-efficacy yang rendah, seseorang yang tidak mempunyai kemampuan untuk mengatasi tantangan dalam hidupnya, maka orang tersebut akan merasa cemas disaat dihadapkan pada tantangan tersebut. Sebaliknya jika orang tersebut merasa mampu menhadapi tantangan, maka ia tidak akan dihantui oleh kecemasan atau rasa takut. Orang dengan self-efficacy rendah akan cenderung fokus pada ketidakmampuan atau ketidakadekuatannya (Nevid, Rathus \& Greene, 2005).

Self efficacy sendiri dapat memunculkan rasa optimis yang akhirnya menimbulkan emosi-emosi positif dan menghindarkan seseorang dari emosi-emosi negatif seperti depresi. (Luszczynska, Scholz, \& Schwarzer, 2005). Self efficacy merupakan dasar dari pola pikir, perasaan dan motivasi untuk menyalurkan segala kemampuannya dalam mencapai tujuannya. Seseorang yang kurang memiliki kepercayaan terhadap kemampuannya cenderung akan menghindari kejadian-kejadian yang dirasa mengancam dirinya. Rasa percaya terhadap kemampuan diri penting untuk menumbuhkan motivasi yang menjadi dasar pola pikir sehingga dapat mempengaruhi perilaku seseorang.

Berdasarkan alasan-alasan diatas maka kecemasan mahasiswa yang sedang mengerjakan skripsi dapat dipengaruhi oleh beberapa faktor dan peneliti memilih self efficacy karena peneliti ingin mengetahui hubungan self efficacy dengan kecemasan pada mahasiswa yang sedang mengerjakan skripsi yang bertunjuan untuk mencari ada atau tidak hubungan antara kedua variabel tersebut. Penelitian ini diharapakan dapat memberikan sumbangan bagi ilmu pengetahuan khususnya dalam bidang Psikologi. Selain itu diharapkan penelitian ini dapat membuat mahasiswa lebih percaya pada kemampuan mereka dalam mengerjakan skripsi, sehingga mereka dapat meminimalisir kecemasannya.

Kecemasan adalah suatu keadaan khawatir tentang sesuatu yang buruk akan segera terjadi (Nevid, Rathus \& Greene, 2005). Sementara Feist dan Feist (2006) mengartikan bahwa kecemasan adalah suatu keadaan gelisah atau tidak menyenangkan yang diiringi dengan sensasi pada tubuh atau fisik. Kecemasan dapat menyebabkan suatu rasa takut dan kekhawatiran pada diri individu. Disaat seseorang memiliki rasa percaya pada kemampuan yang rendah dalam mengerjakan skripsi, maka akan muncul pemikiran bahwa mereka tidak mampu mengerjakan skripsinya sehingga menimbulkan suatu perasaan tidak berdaya dan cenderung akan menghindari pengerjaan skripsinya, perasaan tidak mampu dan tidak berdaya inilah yang memicu munculnya kecemasan dalam mengerjakan skripsi (Nevid, Rathus \& Greene, 2005).

Kecemasan dapat juga menjadi suatu yang bermanfaat ketika hal tersebut memotivasi atau mendorong kita untuk melakukan pekerjaan seperti belajar sebelum 
ujian. Tetapi kecemasan itu dapat menjadi sesuatu yang merugikan saat kecemasan tersebut tidak sesuai dengan ancaman yang ada dan respon yang muncul berlebihan sehingga menggangu fungsi kehidupan seseorang (Nevid, Rathus \& Greene, 2005).

Kecemasan dapat muncul dari beberapa faktor berikut. Pertama, faktor genetik atau hereditas, seseorang yang lahir dalam keluarga yang memiliki gangguan kecemasan memiliki kecenderungan untuk mengalami kecemasan jika dibandingkan dengan orang lain meskipun dalam kondisi yang sama. Kedua, faktor trauma mental yang sangat berhubungan dengan pengalaman tidak menyenangkan yang pernah dialami dan pengalaman tersebut menimbulkan trauma dalam diri seseorang. Ketiga, tidak berjalanya coping atau mereka upaya yang digunakan untuk mengatasi ancaman yang ada gagal atau bisa kurang berhasil. Keempat adalah adanya pemikiran irasional artinya orang tersebut memiliki keyakinan yang tidak masuk akal terhadap ancaman yang dihadarinya (Wolman, dalam Oktary 2007).

Kecemasan memiliki empat gejala. Pertama, gejala somatis yang mencakup otototot tegang, denyut jantung meningkat dan keringat meningkat. Kedua, gejala behavioral yang mencakup melarikan diri, menghindar, agresi, nafsu makan menurun dan merasa enggan atau malas. Ketiga, gejala emosional yang mencakup merasa takut, merasa diteror dan gelisah. Keempat, gejala kognitif mengantisipasi bahaya, melebih-lebihkan sesuatu (bahaya), konsentrasi terggangu kewaspadaan yang berlebihan, khawatir, takut hilang kontrol dan rasa takut yang tidak nyata (Nolen, 2001).

Ada beberapa cara untuk mengendalikan kecemasan seseorang, pertama berusaha bekerja lebih efektif dalam menghadapi objek atau situasi yang dapat menimbulkan kecemasan dan ketakutan, dengan melakukannya sendiri atau meminta bantuan dan saran dari orang terpercaya. Kedua, mengidentifikasi atau menganalisa keyakinan yang dapat mengakibatkan keyakinan. Ketiga, mengahadapi objek dan situasi yang menyebabkan muculnya rasa cemas hingga dorongan untuk menghindar menjadi berkurang. Keempat, self relexation atau belajar mengantikan pikiran-pikiran negatif dengan pikiran-pikiran positif (Nevid, Rathus \& Greene, 2005).

Self-efficacy merupakan salah satu aspek utama dari social cognitif Bandura yang berarti keyakinan terhadap kemampuan untuk melakukan tindakan tertentu yang diperlukan untuk mencapai hasil yang diinginkan (Luszczynska, Scholz, \& Schwarzer, 2005). Self-efficacy menjadi suatu pertimbangan apakah ketrampilan dan kemampuan seseorang dapat membawa pada suatu keberhasilan dalam mengerjakan tugas tertentu (Frager \& Fadiman, 2006). Self-efficacy mendorong untuk mengatur dalam mencapai tujuan dan meningkatkan tujuan seseorang, mengarahkan kegiatan, dan memacu semangat dalam menghadapi kejadian yang tidak terelakkan ataupun dalam kesulitan. Kognitif memiliki hubungan dengan keyakinan yang muncul bahwa dirinya mampu atau tidak mampu dalam melaksanakan suatu hal yang dianggap memuaskan (Bandura 1977). Self efficacy merupakan suatu kontruksi universal, yang artinya keyakinan dasar pada setiap individu itu sama (Bandura, dalam Luszczynska, Dona \& Schwarzer 2005).

Self-efficacy dapat diperoleh, dapat meningkat ataupun menurun melalui empat faktor. Pertama, mastery experience, self-efficacy dapat meningkat karena dapat menyelesaikan tugas yang sulit. Kedua, social modeling, self-efficacy dapat meningkat 
saat kita melihat prestasi orang lain dengan kompetensi yang sama. Ketiga, social persuasion, self-efficacy dapat diperoleh atau menurun karena adanya bujukan dari orang lain. Keempat, physical and emotion state, adanya emosi yang kuat terkadang menurunkan kemampuan : ketika seseorang mengalami pengalaman yang menakutkan, kecemasan yang berlebihan (akut) atau memiliki tingkat stres yang tinggi mereka mempunyai harapan tentang keberhasilan yang rendah.

\section{Hipotesis}

Ada hubungan antara self efficacy dengan kecemasan mahasiswa yang akan mengerjakan skripsi. Semakin tinggi self efficacy seseorang maka kecemasan yang dimilikinya akan semakin rendah, begitu pula sebaliknya semakin rendah self efficacy seseorang akan semakin tinggi pula kecemasan yang dirasakan.

\section{Metode}

\section{Rancangan Penelitian}

Dalam pengambilan data digunakan pendekatan kuantitatif korelasional karena penelitian ini bertujuan untuk mengetahui korelasi antara dua variabelnya, dan juga untuk menguji signifikansinya.

\section{Subjek Penelitian}

Dalam penelitian ini digunakan populasi dari mahasiswa Universitas Ibrahimy yang sedang mengerjakan skripsi. Penentuan jumlah sampel dari populasi tersebut menggunakan tabel yang dikembangkan oleh Isaac dan Michael. Populasi subjek berjumlah 293 sehingga jumlah sampel yang digunakan adalah 161, dengan taraf signifikan 5\% (Sugiyono, 2009).

\section{Variabel dan Instrumen Penelitian}

Variabel terikat dalam penelitian ini adalah kecemasan. Kecemasan mengerjakan skripsi merupakan suatu keadaan khawatir dan gelisah terhadap skripsi yang dianggap suatu ancaman bagi kelulusan mahasiswa dan diiringi dengan sensasi pada tubuh atau fisik (gejala somotis). Skala yang digunakan untuk mengukur kecemasan adalah Skala Kecemasan Dalam Proses Mengerjakan Skripsi yang disusun oleh peneliti dan berjumlah 24 item. Item-item tersebut disusun berdasarkan empat indikator yaitu gejala somatis, gejala behavioral, gejala emosional dan gejala kognitif. Skala ini terdiri dari 24 pernyataan yang yang berbentuk skala Likert dengan 4 point $(1=$ sangat tidak sesuai, 2 = tidak sesuai, 3 = sesuai, dan 4 = sangat sesuai), yang terdiri dari 12 item favorable dan 12 item unfavorable.

Variabel bebas dalam penelitian ini adalah self-efficacy. Self-efficacy merupakan keyakinan mahasiswa dengan kemampuan mereka untuk menghasilkann suatu pencapaian. Skala yang digunakan untuk mengukur self efficacy adalah General Self Efficacy Scale (GSE). Aspek dari skala tersebut adalah self efficacy itu sendiri sebagai 
bagian dari aspek social cognitif Bandura. Skala tersebut disusun oleh Rafl Schwarzer \& Matthias Jerusalem untuk mengukur self efficacy secara luas yang telah diterjemahkan kedalam 25 bahasa dengan cronbach alpha antara 0.75 sampai 0.91 (Scholz, Dona, Sud \& Schwarzer, 2002). Skala ini terdiri dari 10 pernyataan yang yang berbentuk skala Likert dengan 4 point ( $1=$ sangat tidak sesuai, $2=$ tidak sesuai, $3=$ sesuai, dan $4=$ sangat sesuai).

\section{Validitas Instrumen}

Berikut ini adalah hasil validitas alat ukur yang telah dilakukan oleh peneliti :

Tabel 1. Indeks Validitas Alat Ukur Penelitian

\begin{tabular}{|c|c|c|c|c|}
\hline Alat Ukur & $\begin{array}{l}\text { Jumlah } \\
\text { Diujikan }\end{array}$ & Item & $\begin{array}{l}\text { Jumlah Item } \\
\text { Valid }\end{array}$ & $\begin{array}{l}\text { Indeks } \\
\text { Validitas }\end{array}$ \\
\hline $\begin{array}{l}\text { Skala } \\
\text { Kecemasan }\end{array}$ & 24 Item & & 19 item & $0,322-0,630$ \\
\hline $\begin{array}{ll}\text { Skala } & \text { Self } \\
\text { Efficacy } & \end{array}$ & 10 Item & & 10 item & $0,403-0,789$ \\
\hline
\end{tabular}

Uji validitas pada skala kecemasan yang terdiri dari 24 item didapatkan 5 item dinyatakan tidak valid dan 19 item dinyatakan valid. Indeks validitas dari skala kecemasan berkisar antara 0,322 - 0,630. Sedangkan pada skala self efficacy semua item dinyatakan valid dan mempunyai indeks validitas antara 0,403 - 0,789. Suatu item dapat dikatakan valid jika memiliki indeks validitas 0,30 .

\section{Reliabilitas Intrumen}

Tabel 2. Indeks Reliabilitas Alat Ukur Penelitian

\begin{tabular}{ccc}
\hline Alat Ukur & Cronbach's Alpha & Keterangan \\
\hline Skala Kecemasan & 0,705 & Reliabel \\
Skala Self Efficacy & 0,775 & Reliabel \\
\hline
\end{tabular}

Berdasarkan tabel diatas dapat disimpulkan bahwa kedua skala yang digunakan dapat dikatakan reliabel karena memiliki cronbrach alpha lebih dari 0,60 atau 60\%. Hal ini menunjukkan bahwa kedua skala yang digunakan dalam penelitian memiliki validitas dan reliabilitas yang memenuhi syarat

\section{Prosedur Penelitian}

Analisis data yang digunakan untuk mengetahui adakah hubungan antara self efficacy dengan kecemasan pada mahasiswa yang akan mengerjakan skripsi adalah dengan menggunakan korelasi product moment dengan menggunakan progam SPSS for Windows versi 17.00. Analisis korelasi product moment itu sendiri digunakan untuk melukiskan hubungan antara dua variabel. 


\section{Hasil}

Berdasarkan hasil penelitian yang telah dilakukan pada 161 responden, didapatkan 94 responden atau 58,4\% yang memiliki self efficacy yang tinggi. Sedangkan 67 responden atau 41,6\% lainnya memiliki self efficacy yang rendah. Selain itu diperoleh pula data mengenai kecemasan mahasiswa yang sedang mengerjakan skripsi yaitu 82 atau 50,9 \% orang yang mengalami kecemasan yang tinggi, sedangkan 79 orang atau 49,1 \% memiliki kecemasan yang rendah. Hal tersebut ditunjukkan pada tabel berikut :

Tabel 4. Deskripsi Self Efficacy dan Kecemasan

\begin{tabular}{cccccc}
\hline \multirow{2}{*}{ Skala } & \multicolumn{2}{c}{ Frekuensi } & \multicolumn{2}{c}{ Persentase } & Standart \\
& Tinggi & Rendah & Tinggi & Rendah & Deviasi \\
\hline Self Efficacy & 94 & 67 & $58,4 \%$ & $41,6 \%$ & 3,13 \\
Kecemasan & 79 & 82 & $49,1 \%$ & $50,9 \%$ & 6,49 \\
\hline
\end{tabular}

\section{Hasil Analisa Data}

Berdasarkan penelitian yang telah dilakukan, pada tabel 5 skala kecemasan didapatkan aspek somatis memiliki rata-rata 2,319, aspek behavioral memiliki nilai rata-rata 2,286, aspek emosional memiliki nilai rata-rata 2,595 dan pada aspek kognitif memiliki nilai rata-rata 2,130. Dari data tersebut dapat diartikan bahwa kecemasan terbesar yang dialami subjek terletak pada aspek emosional.

Tabel 5. Mean dan Standart Deviasi Skala Kecemasan

\begin{tabular}{ccccc}
\hline & \multicolumn{4}{c}{ Aspek Kecemasan } \\
& Somatis & Behavioral & Emosional & Kognitif \\
\hline Mean & 2,319 & 2,286 & 2,595 & 2,130 \\
$\begin{array}{c}\text { Standart } \\
\text { Deviasi }\end{array}$ & 0,749 & 0,800 & 0,840 & 0,668 \\
\hline
\end{tabular}

Berdasarkan hasil perhitungan korelasi product moment didapatkan data sebagai berikut:

Tabel 6. Korelasi Self Efficacy dengan Kecemasan Mergerjakan Skripsi pada Mahasiswa

\begin{tabular}{lc}
\hline \multicolumn{1}{c}{ Koefisien } & Indeks Analisis \\
\hline Koefisien Korelasi $(\boldsymbol{r})$ & $-0,606$ \\
Koefisien Determinasi $\left(\boldsymbol{r}^{2}\right)$ & 0,367 \\
Taraf Kemungkinan Kesalahan & $1 \%(0,01)$ \\
$\boldsymbol{P}$ (Nilai Signifikansi) & 0,000 \\
\hline
\end{tabular}

Berdasarkan tabel 6 didapatkan nilai koefisien korelasi $(r)=-0,606$ yang menunjukkan adanya hubungan negatif antara self efficacy dengan kecemasan pada mahasiswa yang sedang mengerjakan skripsi. Sedangkan nilai signifikansi $(p)=0,000$ 
yang artinya sangat signifikan. Koefisien korelasi yang negatif mengindikasikan bahwa hubungan yang terbentuk antara self efficacy dengan kecemasan adalah berbanding terbalik atau tidak searah artinya apabila semakin tinggi self efficacy maka kecemasan seseorang semakin rendah, begitu juga sebaliknya. Pada tabel koefisien determinan $\left(r^{2}\right)$ menunjukan nilai sebesar 0,367 yang berarti variabel self efficacy memberikan sumbangan efektif pada kecemasan mahasiswa dalam mengerjakan skripsi sebesar $36,7 \%$ dan 63,3\% dipengaruhi oleh faktor yang lain. Berdasarkan penjelasan diatas menunjukkan bahwa hipotesis $\left(\mathrm{H}_{0}\right)$ diterima yang artinya semakin tinggi self efficacy maka akan semakin rendah kecemasan mahasiswa yang sedang mengerjakan skripsi, begitu juga sebaliknya.

\section{Pembahasan}

Berdasarkan penelitian yang telah dilakukan membuktikan bahwa, self efficacy dengan kecemasan mahasiswa skripsi memiliki taraf kemaknaan sebesar $(r)=-0,606$. Sedangkan taraf kesalahannya adalah $(p)=0,000$ yaitu sangat signifikan yang berarti self efficacy memiliki hubungan negatif dengan kecemasan pada mahasiswa yang sedang mengerjakan skripsi. Self efficacy dan kecemasan mahasiswa skripsi menunjukkan ke arah negatif yaitu semakin tinggi self efficacy maka akan semakin rendah kecemasan mahasiswa skripsi, begitu juga sebaliknya. Dengan kata lain hal ini membuktikan bahwa hipotesa penelitian mengenai hubungan antara self efficacy dengan kecemasan pada mahasiswa yang sedang mengerjakan skrispi dapat diterima. Hal tersebut membuktikan bahwa self efficacy yang rendah akan menyebabkan kecemasan yang tinggi pada mahasiswa skripsi, dan sebaliknya self efficacy yang tinggi akan menyebabkan kecemasan mahasiswa semakin rendah

Seseorang dengan self efficacy yang rendah akan cenderung merasa tak berdaya saat dihadapkan pada hambatan dalam menjalankan tugas atau pekerjaan mereka. Mereka akan merasa tidak mampu mengerjakan pekerjaan yang ada sehingga hal itu membuat mereka lebih mudah menyerah, putus asa takut dan menghindar. Orang dengan self efficacy yang rendah sering kali merasa ragu sebelum mengerjakan sesuatu pekerjaan yang dirasa dirinya tidak mampu untuk menyelesaikan hal tersebut dan hal tersebut dapat menjadi ancaman bagi dirinya. Ancaman-ancaman tersebut dapat menjadi suatu beban atau tekanan dalam diri dan saat hal tersebut tidak dapat dihindari sehingga menimbulkan kecemasan dalam diri. Sedangkan orang dengan self efficacy yang tinggi memiliki kepercayaan terhadap kemampuan mereka dalam menghadapi suatu permasalahan. Orang-orang seperti ini menganggap bahwa tugas merupakan suatu tantangan bukan merupakan beban atau ancaman. Sehingga orang-orang dengan self efficacy yang tinggi memiliki tingkat kecemasan lebih rendah dari pada mereka yang memiliki self efficacy yang rendah.

Dalam penelitian tersebut menunjukkan kecemasan dengan rata-rata aspek tertinggi terlatak pada aspek emosional yaitu 2,59 yang berarti bahwa kecemasan tertinggi pada mahasiswa yang mengerjakan skripsi terletak pada emosional mereka. Self efficacy sendiri memiliki hubungan dengan emosi negatif ataupun emosi positif. 
Self-efficacy mengarah ke pemecahan masalah yang efektif, diikuti oleh kenaikan emosi positif (Bandura, 1977). Rendahnya self-efficacy berhubungan dengan emosi negatif dan ketidakberdayaan seseorang yang merasa terbebani tanpa memiliki keyakinan terhadap kemampuannya dalam menyelesaikan masalah memiliki kecenderungan untuk mengalami emosi-emosi negatif seperti kecemasan dan dapresi (Luszczynska, Dona, \& Schwarzer, 2005).

Penelitan sebelumnya mengatakan bahwa self efficacy memiliki hubungan dengan prestasi akademik seserorang (Luszczynska, Dona, \& Schwarzer, 2005). Mahasiswa yang memiliki self efficacy yang rendah dalam mengerjakan skripsinya akan mengalami tingkat kecemasan yang tinggi. Hal tersebut terjadi karena mereka merasa tidak yakin terhadap kemampuan kognitif sehingga mengakibatkan mereka kesulitan dalam mencapai hasil yang diinginkan dan akhirnya memunculkan perilaku menghindar karena rendahnya self efficacy (Bandura, 1977). Self efficacy dapat memunculkan rasa optimis pada mahasiswa yang sedang mengerjakan skripsi, yang nantinya dapat membawa mahasiswa pada emosi-emosi positif dan akan menghindarkan mereka pada emosi-emosi negatif, yang dapat mengakibatkan kebingungan kognitif, seperti kecemasan (Luszczynska, Scholz, \& Schwarzer, 2005).

Kecemasan memiliki dua elemen utama (Roger, dalam Oktary 2007), pertama bahwa rasa takut terhadap beban eksternal yang dianggap sebagai ancaman bagi dirinya. Sedangkan jika dikaitkan dengan mahasiswa yang mengerjakan skripsi merasa terbebani dengan skripsi yang menjadi faktor eksternal tersebut karena skripsi merupakan syarat untuk kelulusan dari universitas yang nantinya akan diujikan oleh dosen. Elemen kedua adalah rasa khawatir pada kemampuan untuk mengatasi ancaman atau permasalahan yang ada. Hal ini berhubungan dengan sebarapa besar keyakinan mahasiswa untuk dapat menyelesaikan skripsinya dan keyakinan mereka terhadap penelitian mereka. Hal tersebut menunjukkan bahwa self efficacy begitu penting dalam mengerjakan skripsi agar mereka terhindar dari rasa cemas.

Jadi dapat disimpulkan bahwa mahasiswa yang sedang mengerjakan skripsi akan memiliki kecemasan yang tinggi ketika mereka memiliki self efficacy yang rendah. Hal tersebut terjadi karena mereka merasa tidak memiliki kemampuan dan tidak berdaya sehingga melemahkan kognitif mereka, yang dibutuhkan agar dapat menyelsaikan skripsi. Namun kecemasan mahasiswa terhadap skripsi mereka tidak hanya dipengaruhi oleh self efficacy saja tetapi banyak faktor lainya yang mempengaruhi kecemasan. Berdasarkan penelitian ini diketahui bahwa self efficacy memiliki konstribusi terhadap kecemasan mahasiswa yang sedang mengerjakan skripsi sebesar $36,7 \%$ dan berarti ada sekitar 63,3\% menunjukkan ada faktor lain yang mempengaruhi kecemasan mahasiswa dalam mengerjakan skripsi.

\section{Kesimpulan}

Dari hasil penelitian yang telah dilakukan dapat disimpulakan bahwa ada korelasi negatif yang sangat signifikan antara self efficacy dengan kecemasan mahasiswa pada saat mengerjakan skripsi dengan hasil analisa menunjukan nilai $r$ sebesar -0,606 
dengan nilai $p$ sebesar 0,000. Berdasarkan hal tersebut dapat disimpulkan bahwa semakin tinggi self efficacy maka akan semakin rendah pula tingkat kecemasan mahasiswa saat mengerjakan skripsi. Self efficacy sendiri memiliki kontribusi sebesar $36,7 \%$ terhadap tingkat kecemasan mahasiswa yang sedang mengerjakan skripsi dan sisanya 63,3\% dipengaruhi oleh faktor lain.

\section{Referensi [Cambria 12 bold]}

Alwilsol. (2010). Psikologi kepribadian. Malang : UMM Press.

Bandura, A. (1977). Self-efficacy: toward a unifying theory of behavioral change. Psychological Review. 84, 191-215

Eisner, L., Johnson, S., \& Carver, C. (2009). Positive affect regulation in anxiety disorders. Journal of Anxiety Disorders. 23, 645 - 649.

Feist, J. \& Feist, G. (2006). Theories of personality. New York: Mc GrawHill

Frager, R. \& Fadiman, J. (2006). Personality and personal growth sixth edition.New Jersey : Pearson Education, Inc

Juárez, F.,\& Contreras, F., (2008). Psychometric properties of the general self-efficacy scale in a colombian sample. International Journal of Psychological Research, 1 612.

Kashdan, T., Volkmann, J., Breen, W., \& Han, S. (2007). Social anxiety and romantic relationships: The costs and benefits of negative emotion expression are contextdependents. Journal of Anxiety Disorders. 21, 475 - 492

Kerlinger. (2000). Asas-asas penelitian behavioral. Yogyakarta : Gadjah Mada University Press.

Luszczynska, A., Scholz, U., \& Schwarzer, R. (2005). The general self-efficacy scale: Multicultural validation studies. The Journal of Psychology. 139, 439 - 457.

Luszczynska, A., Dona, B,. \& Schwarzer, R. (2005). General self-efficacy in various domains of human functioning: Evidence from five countries. International Journal of Psychology. 40, $80-89$.

Marco, I. (2013). Relationship between temperament And anxiety disorders: a systematic review. Mediterranean Journal Of Clinical Psychology. I, 1

Nevid, S., Rathus, A. \& Greene, B. (2005). Psikologi abnormal. Jakarta : Erlangga.

Nolen, S. (2001). Abnormal psychology second edition. New York: Mc GrawHill.

Nolen, S. \& Hoeksema (2000). The role of rumination in depressive disorders and mixed anxiety/depressive symptoms. Journal of Abnormal Psychology. 109, 504 - 511.

Oktary, M.A.K. (2007). Hubungan self efficacy dengan kecemasan pada mahasiswa yang sedang mengerjakan skripsi. Skripsi. Depok : Fakultas Psikologi Universitas Indonesia.

Schneider,W.R. (2011). The relationship between statistics self-efficacy, statistics anxiety, and performance in an introductory graduate statistics course. Disertasi doktoral. University of South Florida. 
Schunk, D. (1991). Self-efficacy and academic motivation. Educational Psychologist. 26, 207-231.

Sugiyono. (2009). Metode penelitian kuantitatif kualitatif dan R\&D. Bandung : Alfabeta.

Suryaningrum, C. \& Asrori, A. (2009). Terapi kognitif perilaku unutk mengatasi kecemasan bimbingan skripsi. Laporan Penelitian. DPP. (2009). Malang : Universitas Muhammadiyah Malang

Schwarzer, R., \& Renner, B. (2000). Social-cognitive predictors of health behavior: Action self-efficacy and coping self-efficacy. Health Psychology. 19, 487 - 495.

Scholz, U., Doña, B., Sud, S., \& Schwarzer, R. (2002). Is general self-efficacy a universal construct? Psychometric findings from 25 countries. European Journal of Psychological Assessment. 18, 242 - 251. 